\title{
Breed effects of three commercial broiler chickens reared in the tropics on performance, carcass, serum and haematological parameters
}

$*^{1}$ Olajide, R., ${ }^{2}$ Laoye, O. A. and ${ }^{2}$ Banjoko, O. J.

${ }^{I}$ Department of Animal Production and Health, University of Africa,

Toru-Orua, Bayelsa State, Nigeria

${ }^{2}$ Department of Animal Science and Production, Joseph Ayo Babalola University, Ikeji-Arakeji, P.M.B. 5006, Ilesa, Osun State, Nigeria

*Corresponding author: rotimi.olajide@uat.edu.ng; +2348035199681

\begin{abstract}
Performance and other parameters of broiler chickens could be influenced by the environment (feeds, housing, climate) and genetic potentials (breeds). Three hundred (300) broiler chicks comprising of one hundred each of the three breeds designated as $A, B$ and $C$ were used in a completely randomized design experiment which lasted for 56 days. Each breed represents a treatment with 5 replicates of 20 birds each. The birds were fed ad libitum with the same commercial starter and finisher diets throughout the period of the study; and water supplied free of choice. Average final body weight, average daily feed intake, average daily weight gain, feed conversion ratio, cost/kg feed and cost of feed/kg live weight gains at the starter and finisher phase were the performance parameters measured. Carcass, serum and haematological indices of these birds were also investigated. Proximate composition of the experimental starter and finisher diets indicated that both were adequately formulated for birds in the tropics under which the study was carried out. Results of the performance parameters showed that the values were similar for the starters and finishers except for highest $(P<0.05)$ feed intake of $134.68 \mathrm{~g} / \mathrm{b} / \mathrm{d}$ obtained for breed A compared with $112.01 \mathrm{~g} / \mathrm{b} / \mathrm{d}$ and $106.69 \mathrm{~g} / \mathrm{b} / \mathrm{d}$ respectively for breeds $C$ and $B$ at the finisher phase. The highest $(P<0.05)$ cost (210.94) of feed per $\mathrm{kg}$ live weight gain was obtained for breed A than 196.10 and \#190.80 respectively for breeds $B$ and $C$ at the starter phase. The average cost offeed per $\mathrm{kg}$ live weight (1-8 weeks) were 282.54, 270.30 and 269.28 respectively for breeds $A, B$ and $C$; with breed $C$ having the lowest cost. The dressed weights were 62.86, 67.29 and $67.84 \%$ for breeds $A, B$ and $C$ in the same order. The abdominal fat reduced $(P<0.05)$ from $1.52 \%$ in breed $A$ to $1.02 \%$ and $0.77 \%$ in breeds $B$ and $C$. Although the thighs were similar across the breeds, variations in the drumstick, $10.27 \mathrm{~g} / \mathrm{kg}$ breed $A, 11.69 \mathrm{~g} / \mathrm{kg}$ breed $B$ and $10.64 \mathrm{~g} / \mathrm{kg}$ breed $C$ differed $(P<0.05)$. The breast increased $(P<0.05)$ from $18.62 \mathrm{~g} / \mathrm{kg}$ breed A to $20.36 \mathrm{~g} / \mathrm{kg}$ breed $B$ and $21.95 \mathrm{~g} / \mathrm{kg}$ breed C. Globulin and neutrophils were the only blood indices which differed $(P<0.05)$ across the breeds at the starter phase. Breed $C$ was considered the best of the 3 breeds in terms of performance, cost, carcass and health status indicated by blood indices; and could be recommended for commercial broiler production for better economic returns.
\end{abstract}

Keywords: performance, breeds, carcass, blood parameters, health status

\section{Introduction}

The poultry industry is going through a gradual but definite change in product differentiation in response to consumer and industry demands (Chukwuka et al., 2010). To implement these changes, genetic improvements have focused primarily on selection for growth rate, feed conversion efficiency and degree of muscling resulting in gross changes in commercial poultry. Poultry production has undergone rapid changes since 1940's when modern intensive production methods were introduced together with new breeds, 


\section{Breed effects of three commercial broiler chickens reared in the tropics}

improved bio-security and preventive health measures (Permin and Pedersen, 2000). Poultry production provides the opportunity of meeting animal protein intake from livestock industry in Nigeria. It provides ready job for a large number of populations (Olaloku, 1999). It is now by far the largest livestock species worldwide, accounting for more than $30 \%$ of all animal protein consumption (Permin and Pedersen, 2000). Poultry production stemmed from the ancient traditional practices and in general, village producers who kept small flocks of between 2 and 20 birds per household (Gueye, 1997) and they survived as scavengers. Rudimentary shelters might be provided to give some measures of protection against bad weather and night predators such as reptiles (Gueye, 1997). The demand for meat is increasing daily due to increase in population growth. To meet up with this demand at the recommended level, effort of farmers should not only be geared towards increasing poultry production but also rearing strains of chickens with some desirable attributes such as disease resistance, adaptability to tropical/harsh environmental conditions, optimum feed consumption at lower cost yet with greater out-put. The development of suitable strains of broiler chickens for the tropical environment is a research interest which has engaged the attention of a number of poultry geneticists and breeders for the past decades (Nargish et al., 2010). Consumer preference for tender and white meat containing low contents of fat and cholesterol seems to act as catalyst engendering increased broiler production not only at festive periods but all year round. Broiler meat is sold whole or cut into parts for individuals and families who could not afford whole chicken (Olawunmi and Fagbuaro, 2011). The genetic selection of broiler chicken breeds for superior growth rate has arguably been primary method for increasing productivity (Peter et al., 2010). There is evidence that there are genetic differences in growth rate between strain and changes in weight ranking may be critical in the age ranged between eight and twelve weeks (Deeb and Lamont, 2000). Low productivity experienced by broiler meat chicken producers in the tropics may be attributed to lack of selection of improved poultry breeds. Hitherto, little research work has been carried out on different improved breeds of broiler chickens by local producers, despite the fact that they are more numerous. There is need for research efforts to compare the performance of the various available and popular breeds of broilers with the aim of recommending the best to the farmers. Investigating the blood profiles also has several benefits. According to Kral and Suchy (2000), these include accurate interpretation of health status of birds, diagnostic and management purposes, useful in development of new broiler strains which are genetically resistant to poultry diseases; as well as for genetic improvement of industrial and indigenous poultry. This study investigated the performance, haematological and serum biochemistry; carcass and organ parameters of the three most commonly reared breeds of broiler chickens under tropical condition.

\section{Materials and methods Experimental site}

The study was carried out at the Teaching, Research and Entrepreneurial farm of Joseph Ayo Babalola University, Ikeji Arakeji, Osun State, Nigeria. Further laboratory analyses were done at the Microbiology Laboratory of the Federal University of Technology, Akure which is about 20 minutes drive away from site of the experiment. 


\section{Olajide, Laoye and Banjoko}

Experimental birds and their management Three hundred (300), one day old broiler chicks comprising of one hundred A, B and $\mathrm{C}$ breeds each, respectively were purchased from reputable hatcheries in Ibadan, Oyo State, Nigeria. Each breed represented a treatment. The experimental chicks were randomly allocated to three treatments according to the breeds of the chicks in a completely randomized design. There were five replicates of 20 birds in each of the replicates. The experimental pen was swept, cleaned, washed and disinfected prior to the arrival of the chicks. Adequate preparations were made for wood shaving, feeders, drinkers and brooding facilities. On arrival, the chicks were unboxed and stabilized in each experimental unit. Feed and water were supplied ad libitum throughout the period of the experiment. All routine and occasional management practices were strictly adhered to and adequate health management practices observed during the period of the experiment. All necessary vaccinations/medications were administered accordingly. The experimental chicks were fed with a commercial feed. The proximate analyses of the starter and finisher feeds are as shown in Table 1. The study lasted for 8 weeks with the first 4 weeks as the starter phase and the last 4 weeks as the finisher phase. The performance parameters monitored are feed intake, weight gain and feed conversion ratio. The cost of a $\mathrm{Kg}$ feed was calculated and was used to compute the cost of feed per $\mathrm{Kg}$ live weight gain of the broiler chicks.

\section{Carcass and organs evaluation}

Carcass evaluation was carried out at the Meat Science Section of the Animal Science Laboratory of the Joseph Ayo Babalola University, Ikeji-Arakeji, Osun State, Nigeria. One hundred and twenty (120) birds at the rate of 40 birds per treatment were randomly selected at the end of 8 th week for carcass evaluation. The birds were starved overnight for 12 hours but allowed access to water. The fasted live weights were recorded and the birds were slaughtered by severing the jugular vein after stunning; and hung upside down for proper bleeding. Well-bled carcasses were scalded, de-feathered and eviscerated. The weights were adequately recorded at each of the processing stages and organs (kidney, lungs, heart, liver and gizzard) weights taken. The intestine and abdominal fat were weighed and recorded. Carcass weights (plucked, eviscerated and dressed weights) were calculated as percentages of live weight. The organ weights were calculated as percentages of carcass weight. The weights were measured with sensitive scale calibrated in grammes.

\section{Haematological and serological characteristics}

Blood samples were collected at the starter phase and the finisher phase of the study. The samples were collected from ten birds per treatment (two birds per replicate), each picked at random. The blood was collected via the wing vein, the area was disinfected with cotton wool dampened with methyl alcohol swab and by vein puncture; $5 \mathrm{mls}$ of blood was drawn and emptied into test tubes and EDTA bottles for serum biochemistry and haematogical parameters determination respectively. All EDTA bottles and samples test tubes were labeled appropriately before collection. The haematological parameters determined include the following: Erythrocyte sedimentation rate (ESR), Packed cell volume (PCV), Red blood cell (RBC), Haemoglobin (Hb), Lymphocytes (LYM), Neutrophils (NEU), Monocytes (MONO), Basophils (BAS) and Eosinophils (EOS); and the biochemical components of the serum that were determined include Glucose (GLU), Total protein (TP), Albumin (ALB) and Globulin GLB). 


\section{Breed effects of three commercial broiler chickens reared in the tropics}

\section{Chemical analysis}

Proximate composition of the starter and finisher diets were determined as described by AOAC (2005). Nitrogen Free Extract (NFE) was determined by difference and Metabolisable Energy (ME) calculated according to the procedure of Pauzenga, $(1985)$ as: $\mathrm{ME}(\mathrm{kcal} / \mathrm{kg})=37 \mathrm{x} \%$ Protein + $81.8 \mathrm{x} \%$ Fat $+35.5 \mathrm{x} \%$ NFE.

\section{Statistical analysis}

Data obtained were subjected to analysis of variance (ANOVA) using SAS Statistical Package (SAS, 1999). The means were separated using Duncan's multiple range test at $5 \%$ level of significance.

\section{Results}

Result of the proximate compositions of the commercial feeds used in this study (Table 1) showed that the dry matter, crude protein, ether extract, crude fiber, ash, nitrogen free extract and metabolisable energy were $91.03 \%, 22.32 \%, 11.45 \%$, $4.10 \%, \quad 7.00 \%, 57.16 \%$ and $3791.63 \mathrm{kcal} / \mathrm{kg}$ DM respectively for the starter diet; and 91.92\%, 18.94\%, 13.86\%, $4.62 \%, \quad 7.43 \%, 47.07 \%$ and 3505.52 $\mathrm{kcal} / \mathrm{kg}$ DM for the finisher diet.

Table 1: Proximate composition of experimental diets

\begin{tabular}{lll}
\hline Parameters & \multicolumn{2}{c}{ Percentage composition } \\
\cline { 2 - 3 } & Starter & Finisher \\
\hline Dry matter (\%) & 91.03 & 91.92 \\
Crude protein (\%) & 22.32 & 18.94 \\
Ether extract (\%) & 11.45 & 13.86 \\
Crude fibre (\%) & 4.10 & 4.62 \\
Ash (\%) & 7.00 & 7.43 \\
Nitrogen free extract (\%) & 57.16 & 47.07 \\
Metabolisable energy (Kcal/kg & 3791.63 & 3505.52 \\
DM) & & \\
\hline
\end{tabular}

Table 2 presents the performance of the three breeds (A, B and C) of the experimental chicks at the starter phase. The average initial body weights of the three breeds were not $(\mathrm{P}<0.05)$ different from each other. All of the performance indices investigated were similar $(\mathrm{P}>0.05)$ except the cost of feed per kg live weight gain which differed $(\mathrm{P}<0.05)$. The highest cost of feed per $\mathrm{kg}$ live weight gain of $<210.94$ obtained for breed A was higher $(\mathrm{P}<0.05)$ than $<196.10$ and $<190.80$ respectively obtained for breeds $\mathrm{B}$ and $\mathrm{C}$. Breed $\mathrm{C}$, despite having the lowest $(P>0.05)$ average initial body weight $(39.87 \mathrm{~g} / \mathrm{b})$ eventually had the highest $(\mathrm{P}>0.05)$ numerical final body weight $(748.22 \mathrm{~g} / \mathrm{b})$. This breed also had the highest $(\mathrm{P}>0.05)$ average daily weight gain $(25.30 \mathrm{~g} / \mathrm{b})$, the lowest average daily feed intake $(\mathrm{P}>0.05)$ of $45.56 \mathrm{~g} / \mathrm{b}$, the lowest $(\mathrm{P}>0.05) \mathrm{FCR}$ (1.80), and finally lowest $(\mathrm{P}>0.05) \operatorname{cost}(<190.80)$ of feed per $\mathrm{kg}$ live weight gain.

Table 2: Performance characteristics of three breeds of broiler starter chicks

\begin{tabular}{lllll}
\hline Parameters & \multicolumn{3}{c}{ Breeds } & SEM \\
\cline { 2 - 4 } & $\mathrm{A}$ & $\mathrm{B}$ & $\mathrm{C}$ & \\
\hline Average initial body weight $(\mathrm{g} / \mathrm{b})$ & 41.12 & 41.89 & 39.87 & 0.67 \\
Average final body weight $(\mathrm{g} / \mathrm{b})$ & 720.39 & 736.22 & 748.22 & 11.39 \\
Average daily weight gain $(\mathrm{g} / \mathrm{b} / \mathrm{d})$ & 24.26 & 24.80 & 25.30 & 0.23 \\
Average daily feed intake $(\mathrm{g} / \mathrm{b} / \mathrm{d}$ & 48.17 & 45.90 & 45.56 & 1.67 \\
Feed conversion ratio & 1.99 & 1.85 & 1.80 & 0.32 \\
Cost per kg feed ( & 106.00 & 106.00 & 106.00 & 0.00 \\
Cost of feed per kg live weight gain $(\#)$ & $210.94^{\mathrm{a}}$ & $196.10^{\mathrm{b}}$ & $190.80^{\mathrm{c}}$ & 8.27 \\
\hline
\end{tabular}

Means with different superscript in the same column are significantly $(\mathrm{P}<0.05)$ different from each other 


\section{Olajide, Laoye and Banjoko}

At the finisher phase (Table 3), the only performance parameter which differed significantly $(P<0.05)$ was the average daily feed intake. The highest

$(134.68 \mathrm{~g} / \mathrm{b} / \mathrm{d})$ was obtained for breed A compared to $112.01 \mathrm{~g} / \mathrm{b} / \mathrm{d}$ and $106.69 \mathrm{~g} / \mathrm{b} / \mathrm{d}$ respectively obtained for breeds $\mathrm{C}$ and $\mathrm{B}$. Breed A which had the lowest $(P>0.05)$ average final body weight $(720.39 \mathrm{~g} / \mathrm{b})$ at the starter phase or average initial body weight at the finisher phase having consumed the highest feed at the finisher phase, had the highest $(P>0.05)$ average final body weight $(1886.93 \mathrm{~g} / \mathrm{b})$ compared with $1708.89 \mathrm{~g} / \mathrm{b}$ and $1655.56 \mathrm{~g} / \mathrm{b}$ respectively for breeds $\mathrm{C}$ and $\mathrm{B}$. The FCR were $2.42,2.44$ and 2.45 respectively for breeds A, B and C. Cost of feed per kg live weight gain were $\$ 237.16$ (breed A), \#239.12 (breed B) and 240.10 (breed C); with breed A having the least at the finisher phase.

Table 3: Performance characteristics of three breeds of broiler chickens at finisher phase (5- 8 weeks)

\begin{tabular}{lllll}
\hline Parameters & \multicolumn{2}{c}{ Breeds } & SEM \\
\cline { 2 - 4 } & $\mathrm{A}$ & $\mathrm{B}$ & $\mathrm{C}$ & 11.39 \\
Average initial body weight $(\mathrm{g} / \mathrm{b})$ & 720.39 & 736.22 & 748.22 & 51.23 \\
Average final body weight $(\mathrm{g} / \mathrm{b})$ & 1886.93 & 1655.56 & 1708.89 & 1.35 \\
Average daily weight gain $(\mathrm{g} / \mathrm{b} / \mathrm{d})$ & 55.55 & 43.78 & 45.75 & 4.54 \\
Average daily feed intake $(\mathrm{g} / \mathrm{b} / \mathrm{d}$ & $134.68^{\mathrm{a}}$ & $106.69^{\mathrm{b}}$ & $112.01^{\mathrm{b}}$ & 0.13 \\
Feed conversion ratio & 2.42 & 2.44 & 2.45 & 0.00 \\
Cost per kg feed $(<)$ & 98.00 & 98.00 & 98.00 & 21.76 \\
Cost of feed per kg live weight gain $(<)$ & 237.16 & 239.12 & 240.10 & \\
a,b Means with different superscripts in the same column are significantly $(\mathrm{P}<0.05)$ different from each other
\end{tabular}

Considering these performance traits from day old till end of $8^{\text {th }}$ week of the study, average of the 2 phases (Table 4$)$, none of the indices was affected $(P>0.05)$ by the breed differences. Best performance was exhibited by breed $\mathrm{C}$ at the starter phase in terms of having the highest final body weight gain; and lowest $(P>0.05)$ average daily feed intake, FCR and cost of feed per $\mathrm{kg}$ live weight gain.

Table 4: Performance characteristics of three breeds of broiler chickens (1-8 weeks)

\begin{tabular}{lcccc}
\hline Parameters & \multicolumn{3}{c}{ Breeds } & SEM \\
\cline { 2 - 4 } & $\mathrm{A}$ & $\mathrm{B}$ & $\mathrm{C}$ & 0.67 \\
\hline Average initial body weight $(\mathrm{g} / \mathrm{b})$ & 41.12 & 41.89 & 39.87 & 51.23 \\
Average final body weight $(\mathrm{g} / \mathrm{b})$ & 1886.93 & 1655.56 & 1708.89 & 1.35 \\
Average daily weight gain $(\mathrm{g} / \mathrm{b} / \mathrm{d})$ & 32.96 & 28.82 & 29.80 & 4.54 \\
Average daily feed intake $(\mathrm{g} / \mathrm{b} / \mathrm{d}$ & 91.43 & 76.30 & 78.79 & 0.13 \\
Feed conversion ratio & 2.77 & 2.65 & 2.64 & 0.00 \\
Cost per kg feedA) & 102.00 & 102.00 & 269.00 & 21.76 \\
Cost of feed per kg live weight & 282.54 & 270.30 & 28 & \\
gain (N) & & & \\
a,bMeans with different superscripts in the same column are significantly (P<0.05) different from each other
\end{tabular}

Carcass and organ parameters of the experimental birds are presented in Table 5. Out of all the indices monitored, only the bled weight, abdominal fat, kidney, pancreas and bursa differed $(P<0.05)$ across the breeds. The bled weight $(91.80 \%)$ obtained in breed A was lower
$(P<0.05)$ than $98.61 \%$ and $97.45 \%$ respectively for breeds $\mathrm{B}$ and $\mathrm{C}$. The highest $(1.52 \%)$ abdominal fat obtained in breed A reduced $(P<0.05)$ to $1.02 \%$ and $0.77 \%$ respectively for breeds $\mathrm{B}$ and $\mathrm{C}$. The highest $(P<0.05)$ value for kidney $(0.07 \%)$ obtained in breed A was similar to $0.04 \%$ obtained in 


\section{Breed effects of three commercial broiler chickens reared in the tropics}

breed $\mathrm{C}$; with both higher $(P<0.05)$ than $0.02 \%$ obtained in breed $\mathrm{B}$. The values of pancreas were $0.17,0.14$ and $0.07 \%$ respectively for breeds $\mathrm{A}, \mathrm{B}$ and $\mathrm{C}$. The corresponding values of bursa of fibricus were $0.22,0.12$ and $0.08 \%$ respectively in the same order. Variations obtained in the other carcass (live weight, plucked weight, eviscerated weight, dressed weight and gizzard fat); and organs (heart, lung, liver, intestine, gizzard and proventriculus) were similar $(P>0.05)$ across the breeds. It is of interest that the highest $(P>0.05)$ dressed weight was obtained in breed $\mathrm{C}$, followed by breed $\mathrm{B}$ and the lowest in breed $\mathrm{A}$. The gizzard fat though not significant also followed the same trend with the abdominal fat with breed A having the highest $(P>0.05)$, followed by breed B and breed C having the lowest value for this parameter.

Table 5: Carcass and organ characteristics of the three breeds of broiler chickens

\begin{tabular}{lllll} 
& \multicolumn{3}{c}{ Breeds } & SEM \\
\cline { 2 - 4 } Parameters & $\mathrm{A}$ & $\mathrm{B}$ & $\mathrm{C}$ & 0.04 \\
Live weight (kg) & 2.57 & 2.48 & 2.43 & 1.46 \\
Bled weight (\%) & $91.80^{\mathrm{b}}$ & $98.61^{\mathrm{a}}$ & $97.45^{\mathrm{a}}$ & 2.10 \\
Plucked weight (\%) & 93.37 & 94.79 & 95.22 & 7.68 \\
Eviscerated weight (\%) & 77.39 & 79.78 & 79.77 & 1.12 \\
Dressed weight (\%) & 62.86 & 67.29 & 67.84 & 0.02 \\
Abdominal fat (\%) & $1.52^{\mathrm{a}}$ & $1.02^{\mathrm{ab}}$ & $0.77^{\mathrm{b}}$ & 0.05 \\
Gizzard fat (\%) & 0.62 & 0.44 & 0.41 & \\
Organs (\% of carcass) & & & & 0.01 \\
Heart & 0.48 & 0.44 & 0.35 & 0.03 \\
Lung & 0.61 & 0.61 & 0.60 & 0.01 \\
Liver & 1.64 & 1.49 & 1.62 & 0.002 \\
Kidney & $0.07^{\mathrm{a}}$ & $0.02^{\mathrm{b}}$ & $0.04^{\mathrm{a}}$ & 0.04 \\
Intestine & 4.39 & 3.56 & 4.14 & 0.05 \\
Full gizzard & 2.22 & 2.15 & 2.35 & 0.01 \\
Empty gizzard & 1.57 & 1.62 & 1.60 & 0.002 \\
Pancreas & $0.17^{\mathrm{a}}$ & $0.14^{\mathrm{ab}}$ & $0.07^{\mathrm{b}}$ & 0.001 \\
Bursa & $0.22^{\mathrm{a}}$ & $0.12^{\mathrm{b}}$ & $0.08^{\mathrm{b}}$ & 0.01 \\
Proventriculus & 0.45 & 0.42 & 0.59 & 0.01 \\
\hline a,b Means with different superscripts in the same column are significantly (P<0 0.05$)$ different from each other
\end{tabular}

The distribution of the carcass parts of the three breeds of broiler chickens is presented in Table 6. The drumstick and breast differed $(P<0.05)$ among the breeds. The highest $(P<0.05)$ value $(11.69 \%)$ of drumstick obtained in breed B compared to
10.64 and $10.27 \%$ respectively obtained for breeds $\mathrm{C}$ and $\mathrm{A}$. The lowest $(P<0.05)$ value $(18.62 \%)$ of breast obtained in breed A increased $(P<0.05)$ to $20.36 \%$ and $21.95 \%$ in breeds $\mathrm{B}$ and $\mathrm{C}$ respectively. Other carcass parts were not affected $(P>0.05)$ by the breed differences.

Table 6: Carcass parts of the three breeds of broiler chickens

\begin{tabular}{lllll}
\hline Parameters & \multicolumn{3}{c}{ Breeds } & SEM \\
\cline { 2 - 4 } & $\mathrm{A}$ & $\mathrm{B}$ & $\mathrm{C}$ \\
\hline Head & 2.42 & 2.51 & 2.20 & 0.12 \\
Neck & 5.99 & 5.49 & 5.02 & 0.16 \\
Leg & 4.71 & 4.87 & 4.68 & 0.22 \\
Drumstick & $10.27^{\mathrm{b}}$ & $11.69^{\mathrm{a}}$ & $10.64^{\mathrm{ab}}$ & 1.34 \\
Thigh & 10.63 & 11.09 & 10.99 & 1.21 \\
Wings & 8.48 & 8.77 & 9.01 & 1.23 \\
Breast & $18.62^{\mathrm{b}}$ & $20.36^{\mathrm{ab}}$ & $21.95^{\mathrm{a}}$ & 1.84 \\
Upper back & 7.01 & 7.42 & 7.48 & 0.44 \\
Lower back & 7.66 & 7.42 & 8.04 & 0.67 \\
a,b Means with different superscripts in the same column are significantly $(\mathrm{P}<0.05)$ different from each \\
other & $\mathbf{1 4 5}$ & \multicolumn{4}{c}{}
\end{tabular}


Table 7 shows the biochemical and haematological indices of the three breeds of chicken used for the experiment at the starter phase. All the values for Erythrocyte sedimentation rate (ESR), Packed cell volume (PCV), Red blood cell (RBC), Haemoglobin (Hb), Lymphocytes (LYM), Monocytes (MONO), Basophils (BAS) and Eosinophils (EOS) among the three breeds were not different $(P>0.05)$ from each other except for Neutrophils (NEU) which had values that were different $(\mathrm{P}<0.05)$. Breed $\mathrm{A}$ had the highest $(P<0.05)$ Neutrophils $(23.80 \%)$ compared with $21.80 \%$ and $20.20 \%$ respectively for breeds $\mathrm{B}$ and $\mathrm{C}$. Breed A also recorded the highest $(P>0.05)$ values for ESR, RBC and BAS, while breed $B$ had the highest values for PCV and eosinophils. Breed $\mathrm{C}$ recorded the highest $(P>0.05)$ values for the lymphocytes and monocytes. The result of the biochemical profile showed that there were no differences $(P>0.05)$ among the three breeds for glucose, total protein and albumin except for globulin which recorded different $(P<0.05)$ values. The highest $(P<0.05)$ globulin $(7.88 \mathrm{~g} / \mathrm{dl})$ was obtained for breed A; and this was higher $(P<0.05)$ than $6.00 \mathrm{~g} / \mathrm{dl}$ (breed C) and $4.63 \mathrm{~g} / \mathrm{dl}$ (breed B).

Table 8 revealed the biochemical and haematological indices of the three breeds of chicken used for the experiment at the finisher phase. All the serum biochemical and haematological indices investigated were not affected $(P>0.05)$ by the breeds at the finisher phase.

\section{Discussion}

The nutritional compositions of the diets were adequate to meet the requirement of broiler starters and finishers irrespective of the breed. The basis for compounding commercial feed for poultry is to meet up with the nutritional requirements of poultry birds (Cerrate and Waldroup, 2009). Most commercially produced poultry feed is produced in granular form for easy and fast conversion to flesh (Cultip et al., 2006); and nutritive value of most commercially produced feed affects the growth performance of broiler chicken either negatively or positively. The proximate composition of the commercial feed used in

Table 7: Serum metabolites and haematological indices of the three breeds of broiler chickens at starter phase

\begin{tabular}{lllll}
\hline Blood parameters & \multicolumn{3}{c}{ Breeds } & SEM \\
\cline { 2 - 4 } & $\mathrm{A}$ & $\mathrm{B}$ & $\mathrm{C}$ & \\
\hline Total protein (g/dl) & 24.42 & 22.08 & 26.16 & 1.43 \\
Albumin (g/dl) & 16.54 & 17.45 & 20.16 & 1.02 \\
Globulin (g/dl) & $7.88^{\mathrm{a}}$ & $4.63^{\mathrm{b}}$ & $6.00^{\mathrm{ab}}$ & 0.95 \\
Glucose (g/dl) & 2.93 & 2.58 & 4.11 & 0.69 \\
Red blood cells ( x 10 $\left.\mathrm{mm}^{-3}\right)$ & 1.94 & 1.86 & 1.80 & 0.52 \\
Esr (mm/hr) & 10.00 & 5.00 & 8.40 & 2.33 \\
Packed cell volume (\%) & 24.40 & 25.40 & 24.00 & 2.11 \\
Haemoglobin (g/100ml) & 8.14 & 8.48 & 8.02 & 0.89 \\
Lymphocytes (\%) & 61.40 & 61.00 & 63.20 & 2.43 \\
Neutrophils (\%) & $23.80^{\mathrm{a}}$ & $21.80^{\mathrm{ab}}$ & $20.20^{\mathrm{b}}$ & 1.21 \\
Monocytes (\%) & 11.60 & 12.60 & 13.40 & 1.03 \\
Basophils (\%) & 2.80 & 2.40 & 2.20 & 0.54 \\
Eosinophils (\%) & 1.20 & 1.80 & 1.00 & 0.17 \\
\hline
\end{tabular}

a,b,Means with different superscripts in the same column are significantly $(\mathrm{P}<0.05)$ different from each other 


\section{Breed effects of three commercial broiler chickens reared in the tropics}

Table 8: Serum metabolites and haematological indices of the three breeds of broiler chickens at the finisher phase

\begin{tabular}{lllll}
\hline Blood parameters & \multicolumn{3}{c}{ Breeds } & SEM \\
\cline { 2 - 4 } & $\mathrm{A}$ & $\mathrm{B}$ & $\mathrm{C}$ & \\
\hline Total protein (g/dl) & 23.92 & 23.34 & 24.80 & 1.02 \\
Albumin (g/dl) & 16.88 & 18.13 & 20.51 & 0.94 \\
Globulin (g/dl) & 7.51 & 5.13 & 6.31 & 0.59 \\
Glucose (g/dl) & 3.08 & 3.37 & 4.72 & 0.57 \\
Red blood cells ( x 10 $\mathrm{mm}^{-3}$ ) & 1.89 & 1.93 & 1.82 & 0.42 \\
Esr (mm/hr) & 9.00 & 6.60 & 9.00 & 2.19 \\
Packed cell volume (\%) & 25.00 & 23.20 & 24.60 & 2.40 \\
Haemoglobin (g/100ml) & 8.64 & 8.14 & 8.04 & 0.98 \\
Lymphocytes (\%) & 62.60 & 59.20 & 67.60 & 5.21 \\
Neutrophils (\%) & 23.60 & 22.60 & 21.60 & 1.02 \\
Monocytes (\%) & 10.60 & 12.80 & 13.80 & 0.94 \\
Basophils (\%) & 2.40 & 2.40 & 2.40 & 0.24 \\
Eosinophils (\%) & 1.60 & 1.60 & 1.20 & 0.26 \\
\hline
\end{tabular}

a,b Means with different superscripts in the same column are significantly $(\mathrm{P}<0.05)$ different from each other

this study meets the nutritional requirement of broiler chicken as recommended by NRC (1994). Traditionally, the salient criteria for appraising the performance of the broiler strains have been growth rate and feed conversion efficiency, and less frequently carcass composition (Cahaner et al., 1987; Cabel and Waldroup, 1991; Rezaei et al., 2004). However, there was no significant difference in the average final weight and average body weight gain per bird per day observed among the three broiler breeds used for this study at the starter, finisher and even on the average of the two phases. Breed $\mathrm{C}$ achieved heavier final body weight and higher weight gain numerically than the other breeds at the starter phase; this could be as a result of the genetic potential of this breed. Similar report of higher final weight and daily weight gain was given by Jana (1989). Breeds A and C recorded the highest and least feed conversion ratio, respectively as lower FCR is better for the producer. The value of feed conversion ratio in this study is lower than the range of $1.97-2.54$ reported by Seven et al. (2008) in broiler chicken. Although the feed intake $(\mathrm{g} / \mathrm{b} / \mathrm{d})$ was not influenced by breed of broiler chicken but numerically, breed A consumed more than the remaining two breeds. The lowest feed intake value recorded by breed $\mathrm{C}$ was efficiently converted to flesh as reflected in the feed conversion ratio and this agrees with the report of Hossain et al. (2011). The cost of feed per $\mathrm{kg}$ live weight gain was influenced by breed. Breed $\mathrm{C}$ recorded the least value which makes it the most economical breed for producers at the starter phase.

Breed A recorded the highest final weight at the finisher phase; and this result disagreed with the report of Peter et al. (2010) who found a higher average final weight for another breed. The difference could be as a result of the effects of environment, feed and other exogenous factors. The range of weight gain per bird per day (43.78-55.55) recorded for the finishers in this study are higher than the range (28.38-32.34g) reported by Wang et al. (2007). The values by these authors, however, fall in line with the range of $28.82-32.96 \mathrm{~g} / \mathrm{b} / \mathrm{d}$ recorded for the average of the two phases in the present study. The efficient use of feed is most frequently expressed as feed conversion ratio (Peter et al., 2010); the values of feed 


\section{Olajide, Laoye and Banjoko}

conversion ratio recorded for the three breeds of broiler chicken used for this study is partially in line with that reported by Kumar et al. (2010) for Hubbard and Ross breeds of broiler chicken. The feed intake per bird per day was influenced by breed of chicken; with breed A consumed more feed than breeds B and C. This opposes the result of Hossain et al. (2011). Breed A, despite having the highest average final body weight, average daily weight gain, lowest FCR and cost of feed per $\mathrm{kg}$ live weight gain at the finisher phase was not able to give the best FCR and cost of feed per $\mathrm{kg}$ live weight gain for weeks 1-8. This probably was because this breed consumed highest feed $(91.48 \mathrm{~g} / \mathrm{b} / \mathrm{d})$, had highest FCR (2.77) and cost of feed per $\mathrm{kg}$ live weight gain ( $\$ 282.54$ ) on the average (weeks 1-8). This breed A also consumed the highest feed, had the highest FCR and cost of feed per $\mathrm{kg}$ live weight gain at the starter phase. Breed $\mathrm{C}$, having the highest average daily weight gain, consumed the lowest feed per day, having the least FCR and cost per $\mathrm{kg}$ feed at the starter phase; coupled with better performance in terms of average daily weight gain $(45.75 \mathrm{~g} / \mathrm{b} / \mathrm{d})$, lower daily feed intake $(112.01 \mathrm{~g} / \mathrm{b} / \mathrm{d})$ though with highest FCR (2.45) which were just 0.41 and $1.22 \%$ higher than for the other 2 breeds; and feed cost per $\mathrm{kg}$ live weight gain ( $\$ 240.10)$ which were not outrageous compared with the other 2 breeds, probably gave this breed (breed C) upper hand on the average (1-8 weeks). The breed had the lowest FCR (2.64) and cost of feed per $\mathrm{kg}$ live weight gain ( $\$ 269.28$ ). Although breed $\mathrm{A}$ had the highest daily weight gain $(32.96 \mathrm{~g} / \mathrm{b} / \mathrm{d})$; the average daily feed intake $(91.43 \mathrm{~g} / \mathrm{b} / \mathrm{d})$ and the highest FCR (2.77) makes it uneconomical compared with breeds B and C. Since a naira saved on cost matters to the farmer, breed $\mathrm{C}$ which gave the lowest cost of feed per $\mathrm{kg}$ weight gain may be favoured by broiler farmers. Breed $\mathrm{C}$ recorded the most economical cost of feed per $\mathrm{kg}$ live weight gain and disagreed with report of Peter (2010) which favoured another strain of broiler chicken. Generally, the performance of these three breeds in the present study was superior to the values recorded for broilers (Bot et al., 2013, Ozung et al., 2013, Ayoola et al., 2015).

There were no variations in the values of live weight, plucked weight, eviscerated weight and dressed weight among the three breeds. Bot et al. (2013) linked the reductions in these parameters to reduction in final live weight of the birds. The difference between the live weight and the bled weight may indicate the volume of blood drained after slaughtering. When the bled weight is too high, it may suggest insufficient drainage or too little blood (anaemic condition) in the birds. The amount of blood drained in the present study, for the 3 breeds ranging from 1.39 $8.20 \%$ compares favourably with the level $(2.5-6.60 \%)$ recommended for normal chickens (Mitruka and Rawnsley, 1981). The amount of blood still left in the carcass may also have negative effects on carcass keeping quality since blood is a good medium for the growth of spoilage microorganisms. The least abdominal fat and gizzard fat obtained in breed $\mathrm{C}$ is a plus for this breed. This is because high level of fat in these organs may reflect much fat in the carcass which is not always desirable by the consumers. Reports have also shown that the cost of producing a unit of fat is more than that of lean meat. Although the liver was not affected by breed differences, however, the highest kidney was obtained in breed A which was similar to breed C; and least in breed B. These organs (liver and kidney) are involved in biotransformation in the body; increased size could be due to need for the organs to handle some toxins. The 3 breeds were however fed the same diet which may suggest that the variations 


\section{Breed effects of three commercial broiler chickens reared in the tropics}

were just as a result of the anatomical differences. The pancrease and bursa of fibricus followed the same trend with the highest values of the 2 organs obtained in breed $\mathrm{A}$ and the least in breed $\mathrm{C}$. The prime cuts of a broiler include the drumstick, thigh and the breast. These parts command higher prices. The highest drumstick was obtained in breed B, while thigh was similar across the 3 breeds. The highest breast value obtained in breed $\mathrm{C}$ is also a plus for this breed. The other parts were similar for the 3 breeds. Values of the breast, wings and drumsticks had been linked to reflect the live weight of the birds (Bot et al., 2013). The dressed weight and prime cuts obtained in the present study for the three breeds are higher than the values obtained for broiler chickens raised in the tropics (Ayoola et al., 2015).

Haematological studies are useful in the diagnosis of many diseases as well as investigation of the extent of damage to blood (Onyeyili et al., 1992; Togun and Oseni, 2005). Haematological studies are of ecological and physiological interest in helping to understand the relationship of blood characteristics to the environment (Ovuru and Ekweozor, 2004) and so could be useful in the selection of animals that are genetically resistant to certain diseases and environmental conditions (Mmereole, 2008; Isaac et al., 2013). Haematological parameters are good indicators of the physiological status of animals (Khan and Zafar, 2005). The haematological values recorded in this study showed that the three breeds of chicken were in good health. The values for ESR, PCV, RBC, Hb, LYM, MONO, BAS and EOS of the three breeds were similar across the breeds; except for NEU (starter phase) where breed A recorded the highest value statistically. This could be attributed to the genetic potential of the breed. The result is in line with Chineke et al., (2006) who reported no significant values for PCV, ESR, $\mathrm{Hb}$ and $\mathrm{RBC}$ in different rabbit breeds. Results of the present study falls within the ranges of $1.58-4.10\left(\mathrm{x} 10^{6} \mathrm{~mm}^{-3)}, 24.90-45.20 \%, 0.67\right.$ $2.48 \%$ and $7.40-13.10(\mathrm{~g} / 100 \mathrm{ml})$, respectively for $\mathrm{RBC}, \mathrm{PCV}$, EOS and $\mathrm{Hb}$ recommended (Mitruka and Rawnsley, 1981). The values recorded for serum metabolites (glucose, total protein and albumin) were also similar for the three breeds which disagreed with the report of Ross et al., (1978) who reported higher values for albumin and total protein. Blood profiles is said to be a reliable health indicator, its variation should display a consistent pattern, with the inter-breed variance component (Nadolski et al., 2006)). Therefore, it is important to investigate blood profiles of indigenous birds for accurate interpretation of health status (Kral and Suchy, 2000). This information, aside from diagnostic and management purposes, can be used for developing new broiler strains that are genetically resistant to poultry diseases as well as for genetic improvement programs of industrial and indigenous poultry. The LYM and BAS values recorded in this study falls within the range that was reported by Talebi et al. (2005) in Arbor acre breed of broilers. The stability in serum biochemical values of three breeds of broilers studied suggests that the commercial feed is adequate for the chickens (Egbunike et al., 2009).

\section{Conclusion}

Results from the study indicated that breed C gave the best performance at the least cost with desirable carcass indices and good health status portrayed by similar serum and haematological parameters to the other two breeds; and could be recommended for commercial broiler producers for better economic returns. 


\section{References}

AOAC, 2005. Official methods of Analysis Association of official Analytical Chemist. $18^{\text {th }}$ Eds. Washington, D.C.

Ayoola, A. A., Egbeyale, L. T., Ekunseitan, D. A., Adegoke, A. V. and Adeyeri, O. P. 2015. The effect of neem (Azadirachta indica) leaf meal on the growth performance and carcass characteristics of broiler chickens. Nigerian J. Anim. Prod. 42 (2): $141-150$.

Bot, M. H., Bawa, G. S. and Abeke, F. O. 2013. Replacement value of maize with African locust beans (Parkia biglobosa) pulp meal on performance, haematological and carcass characteristics of broiler chickens. Nigerian J. Anim. Sci. 15: 59-70.

Cabel, M. C. and Waldroup, P. W. 1991. Effect of dietary protein level and length of feeding on performance and abdominal fat content of broiler chickens. Poultry Science, 70: 1550 -1558 .

Cahaner, A., Dunnington, E. A., Jones, D. E., Cherry, J. A. and Siegel, P. B. 1987. Evaluation of mtwo commercial broiler lines differing in efficiency of feed utilization. Poultry Science, 66: 1101-1110.

Cerrate, S. and Waldroup, P. 2009. Maximum profit feed formulation of broilers. International Journal of Poultry Science, 8: 205-215.

Chineke, C. A., Ologun, A. G. and Ikeobi, C. O. N. 2006. Haematological parameters in rabbit breeds and crosses in humid tropics. Pakistan Journal of Biological Sciences, 9: $2102-2106$.

Chukwuka, O. K., Iheshiulor, M. O., Omede, A. and Ogbuewu, F. 2010. Effect of strain on growth, carcass characteristics and meat quality of broilers reared for 12 weeks. New York Science Journal, 3 (5):132 145.

Cultip, S. E., Hott, J. M., Buchanan, N. P. and Moritz, J. S. 2006. Effect of steam conditioning practices on pellet quality and growing broiler nutritional value. Poultry Science, 85: $51-62$.

Deeb, N. and Lamont, S. J. 2000. Genetic Architecture of growth and body composition in unique chicken population. J. Heredity, 93: 107 118.

Egbunike, G. N., Agiang, E. A., Owosibo, A. O. and Fatufe, A. A. 2009. Effects of protein on performance and haematology of broilers fed cassava peel based diets. Archivos de zootecnica, 58 (224): 656.

Gueye, E. F. 1997. Diseases in village chickens: Control through ethnoveterinary medicine. ILEIA Newsletter, 13 (2): 20 -21.

Hossain, M. A., Suvo, K. B. and Islam, M. M. 2011. Performance and economic suitability of three fastgrowing broiler strains raised under farming condition in Bangladesh. Int. J. Agril. Res. Innov. \& Tech. 1 (1\&2): $37-43$.

Isaac, L. J., Abah, G., Akpan, B. and E k a e t t e, I. U . 2013 . Haematological properties of different breeds and sexes of rabbits. Proc. of the $18^{\text {th }}$ Ann. Conf. of Anim. Sci.Assoc. of Nig., 24-27.

Jana, S. P. 1989. Final Summary Report of 11 random sample broiler test 1980 - 89. Random sample poultry performance testing Centre.Acery Milk Colony, Bombay, India.

Khan, T. A. and Zafar, F. 2005. Haematological study in response to various doses of estrogen in broiler production. Int. J. Poult. Sci., 40 
Breed effects of three commercial broiler chickens reared in the tropics

(10): $748-751$.

Kral, P. and Suchy, P. 2000 . Haematological studies in adolescent breeding cocks. Acta Veterinaria Brno., 69: 189-194.

Kumar, S., Sharadamma, K. C. and Radhakrishma 2010. Effects of a garlic based growth promoter on growth performance and specific pathogenic intestinal microbial counts of broiler chicks. Int. J. Poult. Sci, 9: 244-246.

Mitruka, B. M. and Rawnsley, H. M. 1981. Clinical biochemical and haematological reference values in normal experimental animals. Masson publishing USA Inc. New York.

Mnereole, F. U. C. 2008. The study of haematological parameters in the local chicken. Nigerian Journal of Animal Production, 23 (1): 94-97.

Nadolski, J., Skwarska, J., Kalinski, A., Banbura, M., Sniegula, R. and Banbura, J. 2006 . Blood parameters as consistent predictors of nestling performance in great tits (Parus major) in the wild. Comparative Biochemistry and Physiology - Part A: Molecular and Integrative Physiol., 143: 50 - 54.

Nargish, P., Tapas, K. M., Vijaylaxmi, S., Sabyasachi, S. and Ashok, K. S. 2010. Effect of increasing protein percentage feed on the performance carcass characteristics of the broiler chicks. Asian Journal of Poultry Science, 4 (2): 53 - 59.

NRC, 1994. Nutrient requirements of Poultry, 9th Rev.Ed. Nat. Acad. Press, Washington D.C.

Olaloku, E. A. 1999. Sustainable Animal production for Self-Sufficiency in the $21^{\text {st }}$ Century. Department of Animal Science, University of Ibadan, Nigeria.
Olawumi, S. O. and Fagbuaro, S. S. 2011. Productive performance of three commercial broiler genotype reared in the Derived Savannah Zone of Nigeria. International Journal of Agricultural Research, 6: 798-804.

Onyeyili, P. A., Egwu, G. O., Jibike, G. I., Pepple, O. J. and Gbaegbulan, J. O. 1992. Seasonal variation in haematological indices in the grey breasted guinea fowl (Numida mealagris Gallata pallatas). Nig. J. of Anim. Prod., 18 (2): 108-111.

Ovuru, S. S. and Ekweozor, I. K. E. 2004. Ha em tological changes associated with crude oil ingestion in experimental rabbits. African Journal of Biotechnology, 3 (6): 346 -358 .

Ozung, P. O., Oko, O. O., Ebegbulem, V. N., Evans, E. I., Asuquo, L. E. and Ekpo, J. O. 2013. Utilization of neem leaf meal in boiler diets: Effect on growth, carcass characteristics and internal organs. Proceeding of the $18^{\text {th }}$ Ann. Conf. ASAN, 8-12 Sept., 2013, Abuja: 264 -267; Eds: Akpa, G.N., Dairo, F.A.S., Bawa, G.S., Solomon, I.P., Amaefuele, K.U., Odunsi, A.A.\&Ladokun, A.O.)

Pauzenga, U. 1985. Feeding Parent Stock. Zootecnica International, December 1985, pp.22-24.

Permin, A. and Pedersen, G. 2000. Problems related to poultry production at village level:The possibilities. Proc. of smallholder poultry projects in Eastern and Southern Africa, 22 - 25 May, 2000; Morogoro, Tansania.

Peter, S. O., Gunn, H. H., Immumorin, I. G. and Agaviesor, B. O. 2010. Haematological studies on frizzled and naked neck genotype of Nigerian native chicken 
Rezaei, M., Nassiri, H., Moghaddam, P. R. J. and Kermanshahi, H. 2004. The effect of dietary protein and lysine levels on broiler performance, carcass characteristics and $\mathrm{N}$. excretion. International Journal of Poultry Science, 3 (2): $148-152$.

Ross, J. G., Christie, G., Halliday, W. C. and Jones, R. M. 1978. Haematological and blood chemistry "comparison values" for clinical pathology in poultry. Vet. Rec., 102: 29-31.

SAS, 1999. Statistical Analysis System. User's Guide Statistics SAS Institute Inc. Cary NC27513 USA.

Seven, T. P., Seven, I., Yilmaz, M. and Simisek, U. G. 2008. The effects of turkey propolis on growth and carcass characteristics in broilers under heat stress. Anim. Feed Tech. 146: $137-148$.
Talebi, A., Asri-Rezaei, S., Rozeh-Chai, R. and Sahraei, R. 2005 . Comparative studies on haematological values of broiler strains (Ross, Cobb, Arbor-acres and Arian). Int. J. Poult. Sci., 4: 573 579.

Togun, V. A. and Oseni, B. S. A. 2005. Effect of low level inclusion of biscuit dust in broiler finisher diet on pre-pubertal growth and some haematological parameters on unsexed broilers. Resource Communication of Animal Science, $25(1): 22-24$.

Received: $17^{\text {th }}$ September, 2019 Accepted: $27^{\text {th }}$ December, 2019 